\title{
Nyílt homokpusztagyep helyreállítási lehetőségei akác ültetvények helyén: a kaszálás hosszú távú hatása
}

\author{
Halassy Melinda ${ }^{1}$, Kövendi-Jakó Anna ${ }^{1}$, Bruna Paolinelli Reis ${ }^{2}$, \\ Sáradi Nóra ${ }^{3}$, Szitár Katalin ${ }^{1}$ és Török Katalin ${ }^{1}$ \\ ${ }^{1}$ Ökológiai Kutatóközpont, Ökológiai és Botanikai Intézet, \\ 2163 Vácrátót, Alkotmány u. 2-4.
}

${ }^{2}$ Eötvös Loránd Tudományegyetem, Növényrendszertani, Ökológiai és Elméleti Biológiai Tanszék, 1117 Budapest, Pázmány P. sétány 1/C

${ }^{3}$ Szent István Egyetem, Környezettudományi Doktori Iskola, 2100, Gödöllö, Páter Károly u. 1.

E-mail:halassy.melinda@ecolres.hu

\begin{abstract}
Összefoglaló: A kaszálás hosszú távú hatását vizsgáltuk nyílt homoki gyepek regenerációjára akácállományok felszámolását követően. Három homoki akácállomány került letermelésre 1994/1995 telén. Az akáctönköket vegyszeres lekenéssel kezeltük, majd a terület egy részén évi kétszeri kaszálást alkalmaztunk 1995 és 2001 között. A vegyszeres kezelés sikeresen visszaszorította az akácot a nyíltabb táji környezetben található állományok esetén. Itt a kaszált parcellákon szignifikánsan magasabb borítást értek el a nyílt homoki célfajok, mint a nem kaszált parcellákon, de 22 év alatt sem érték el a referencia gyepekre jellemző értéket, mivel a kaszálás elősegítette az idegenhonos fajok térnyerését is. Míg ültetvényekkel körülvett foltban a nem kaszált parcellákon újra felnőtt az akác, $\mathrm{s}$ a célfajok betelepedése elmaradt. A hosszú távú monitorozás alapján a kaszálás hatékonyan segítette elő a nyílt homokpusztagyep regenerációját letermelt homoki akácosok helyén, de a teljes helyreállításhoz további beavatkozások szükségesek.
\end{abstract}

Kulcsszavak: fehér akác, gyeprestauráció, hosszú távú monitorozás, invázió, vegyszeres kezelés

\section{Bevezetés}

A biológiai invázió az egyik kiemelt veszélyeztető tényező, amely a biológiai sokféleség csökkenéséhez vezet (Sala et al. 2000). A fásszárú inváziós fajok gazdasági megítélése ugyanakkor többnyire pozitív, ami az általában negatív környezeti hatások miatt érdekellentétekhez vezethet (Demeter et al. 2015, Ónodi 2016). A fehér akác (Robinia pseudoacacia Linnaeus) az erdőgazdálkodásban használt fafajok közül a leggyakrabban ültetett idegenhonos faj hazánkban (Bartha et al. 
2012). Ugyanakkor spontán terjedése számos élöhelyet veszélyeztet, többek között a hazai homoki gyepeket (Török et al. 2003, Botta-Dukát 2008).

Az akác legnagyobb hatása a nitrogén-fixációból fakad, amely megnöveli a talaj nitrogéntartalmát és mineralizációs sebességét, ami viszont megváltoztatja a nitrogén és más elemek mennyiségét és körforgását (Corbin \& D’Antonio 2012). Ezek a változások nemcsak a föld feletti vegetációt érintik, elsősorban homogenizációt és a korai szukcessziós nitrogénkedvelő fajok - beleértve idegenhonos fajokat - dominanciáját eredményezve (Vítková et al. 2017), de jelentősen megváltoztathatják a talaj mikrobiális közösségét, ami hosszú távon is akadályozhatja az ökoszisztéma helyreállítását (Corbin \& D’Antonio 2012). Szárazgyepi környezetben e változásokat tovább súlyosbítja, hogy a gyepre telepített erdő a mélyebb talajrétegek kiszáradásához, és ezáltal a talajvíz-utánpótlás csökkenéséhez vezet (Tölgyesi et al. 2020).

1992 óta az Európai Unió LIFE programja 33 projektet finanszírozott az akác eltávolítására, elsősorban az elözönlött száraz élőhelyeken (Vítková et al. 2017). Számos hazai beavatkozás is ismert az akác visszaszorítására, elsősorban a nemzeti parkokhoz köthetően (Bolla 2012, Csiszár \& Korda 2015). Ennek ellenére azonban még nem alakult ki egységes, széles körben elfogadott módszer az akác eltávolítását követő élőhely-helyreállításra (Vítková et al. 2017). Az akácsarjak eltávolítására általában vegyszeres kezelést vagy mechanikus eltávolítást (pl. kaszálást vagy legeltetést) alkalmaznak, továbbá a magról történő felújulás megelőzésére lehet még szükség (Csiszár \& Korda 2015). A kaszálással és a levágott növényi anyag eltávolításával csökkenthető a magas nitrogéntartalmú avar menynyisége, és felgyorsítható a nitrogén kiürülése a talaj felső rétegeiből (Tilman \& Isbell 2015). A talajnitrogén lecsökkenése megnöveli a tápanyagszegény környezethez adaptált célfajok versenyképességét az akáchoz kötődő fajokkal szemben (Török et al. 2014).

Bár sokat tudunk az akácról és annak irtási lehetőségeiről, kevés ismeret áll rendelkezésre az akác eltávolítása utáni hosszú távú változásokról. Jelen munkában a kaszálás hosszú távú hatását vizsgáltuk a nyílt homokpusztagyep helyreállításában fehér akác eltávolítását követően három eltérő táji környezetü kísérleti területen. A kaszálás célja az akácsarjak visszaszorítása, továbbá a nitrogén talajból történő kiürülésének elösegítése volt, mely kedvező feltételeket teremthet a nyílt homokpusztagyepi fajok betelepedéséhez. Kérdéseink az alábbiak voltak: 1. A tönkök vegyszeres kezelésével és rendszeres kezdeti kaszálással hosszabb távon megelőzhető-e az akác felújulása? 2. A kezdeti kaszálás a kontroll területekhez képest felgyorsítja-e a nyílt homokpusztagyepi fajok betelepedését az akác letermelése után? 


\section{Anyag és módszer}

1994 folyamán három mintaterületet választottunk ki a Kiskunsági Nemzeti Park területén: Fülöpháza (54B erdőrészlet, 1 ha); Izsák (68I erdörészlet, 0,4 ha, teljes erdőrészlet); és Bugac (214B erdőrészlet, 1,1 ha) környékén. A kiválasztás szempontjai a következők voltak: (1) a Nemzeti Park felügyelete alá eső, (2) vágásérett (kb. 35 éves) erdőtag legyen, (3) buckaháton helyezkedjen el, és (4) az aljnövényzete szárazságot jelezzen, de ne legyen ún. akáctemető, ahol az akácos a nem megfelelő környezeti feltételek miatt magától összeomlik.

Az akácállományok letermelése 1994/95 telén történt meg. A letermelés után a sarjadzás megakadályozására a levágott tönkök felületét triklopir hatóanyagú GARLON®4E (Dow AgroSciences LLC) vegyszerrel kezeltük. A kezelést szükség szerint megismételtük a sarjak lekenésével/permetezésével 1995 tavaszán. A kaszálás vizsgálatára területenként egy $30 \mathrm{~m} \times 40$ m-es mintaterület jelöltünk ki, amit $12 \mathrm{db} 10 \mathrm{~m} \times 10 \mathrm{~m}$ parcellára osztottunk (1. ábra). A kezelést parcellánként végeztük véletlenszerü elrendezésben (6 kontroll és 6 kaszált parcella). A kaszálást 1995-től 2001-ig évente kétszer végeztük motoros fükasza segítségével a fő

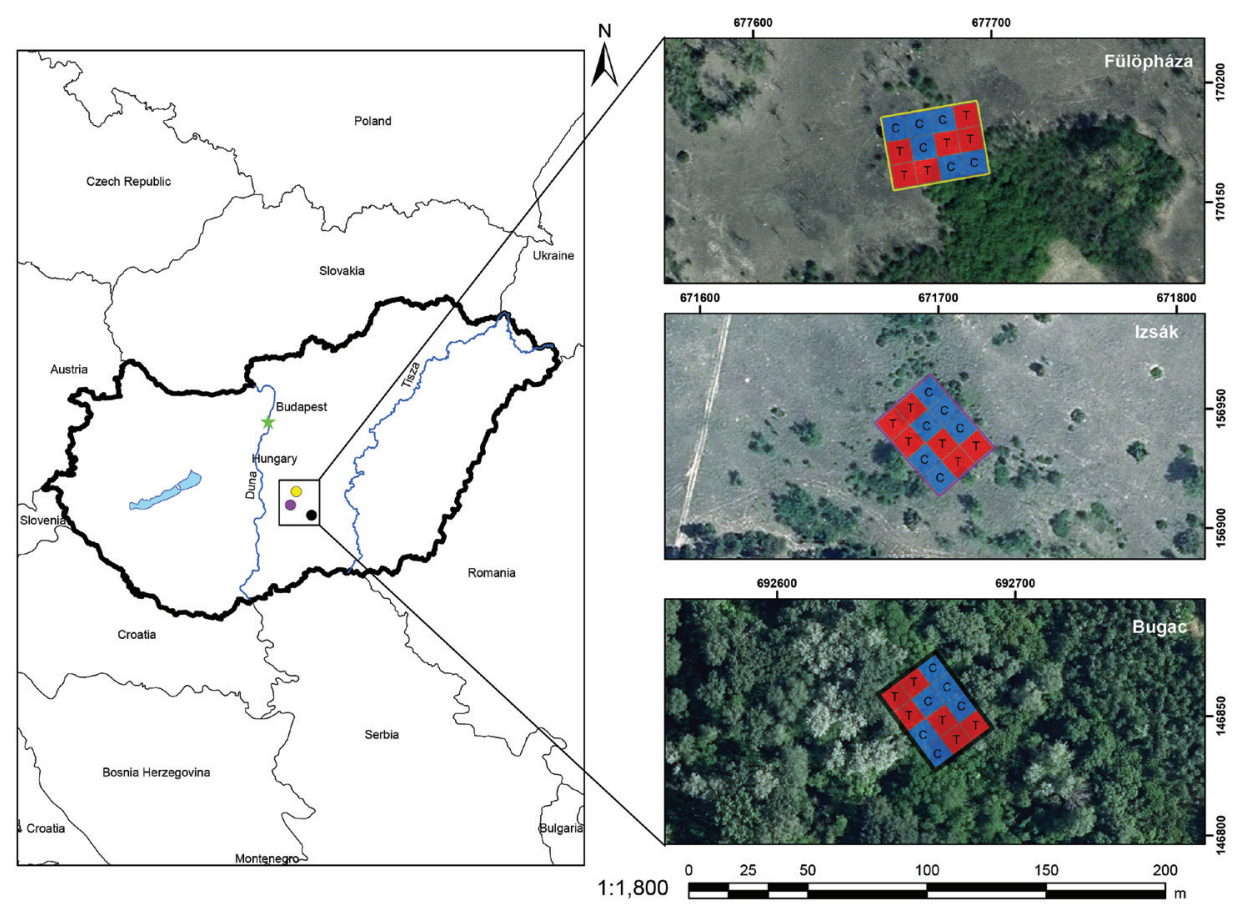

1. ábra: A kísérletek elhelyezkedése a három helyszínen, melyek három különböző táji mátrixot képviselnek. A kezeléseket érintkező $10 \mathrm{~m} \times 10$ m-es parcellákon végeztük. Kék szín jelzi a kontroll (control - C), piros a vágással kezelt (treatment - T) parcellákat. 
vegetációs periódusokban (május/június és augusztus/szeptember fordulóján), amikor a legnagyobb mennyiségü biomassza távolítható el. A kezelt parcellákon minden növényi anyagot levágtunk, és a levágott növényi anyagot ritka fogú gereblyével a parcellákon kívülre hordtuk.

A cönológiai mintavételezést parcellánként $3 \mathrm{db} 2 \mathrm{~m} \times 2 \mathrm{~m}$-es állandó négyzetben végeztük évente kétszer, közvetlenül kaszálás előtt. A monitorozást 1995 és 1999 között évente végeztük, ezután Fülöpházán és Izsákon további hat felvételezés történt (2002, 2003, 2005, 2007, 2009, 2017). A bugaci területen 1999-ben megszünt a további kezelés és monitorozás az akác erős újrasarjadása miatt, és csak 2019-ben felvételeztük újra. A környező tájakban referencia gyepeket is kijelöltünk. Ezek száma kezdetben területenként csak egy volt, majd Fülöpházán és Izsákon 1999-től 18-18 db felvételt készítettünk. 2019-ben a bugaci adatokat is kiegészítettük a közeli homoki gyepből származó 17 referencia felvétellel Ónodi és munkatársai (2014) adatsorából. A cönológiai becslést Braun-Blanquet (1965) módszerét követve végeztük, amit százalékos skálára transzformáltunk át Zólyomi (1951) módszere alapján. A statisztikai elemzésekhez a júniusi és augusztusi felvételekből fajonként az éves maximális értéket vettük figyelembe.

A beavatkozások sikerét három indikátorral mértük: az akác, a nyílt homoki célfajok és az akácon kívül megjelent egyéb idegenhonos fajok borításának változásával. A célfajok besorolásánál Csecserits és munkatársai (2011), az idegenhonos fajok esetén Balogh és munkatársai (2004) munkájára támaszkodtunk, és csak az újjövevény fajokat vettük figyelembe. Az összesen 112 fajból 44 célfaj és 22 idegenhonos faj került be az elemzésbe. Végül az egyes évekre és kezelésekre kiszámoltuk az indikátorok kvadrátonkénti relatív borítását.

A kezelések és évek közötti különbségek tesztelésére lineáris kevert modelleket (LME) alkalmaztunk külön-külön az egyes területekre az akác, a célfajok és idegenhonos fajok relatív borítására az „nlme” csomag felhasználásával (Pinheiro et al. 2017). A kezeléseket (kaszált, kontroll, referencia) és éveket rögzített kategorikus magyarázó változókként, az állandó felvételi négyzeteket random faktorként építettük be a modellekbe. Az idegenhonos fajokra és az akácra vonatkozó modellek csak a kaszált, nem kaszált kezelés párost tartalmazták, mivel ezek az indikátorok gyakorlatilag nulla borítással szerepeltek a referenciákban. A célfajok adatait arkusz-szinusz négyzetgyök, az idegenhonos fajok adatait négyzetgyök transzformációnak vetettük alá, valamint varIdent varianciaszerkezetet használtunk a normalitás és a homoszkedaszticitás feltételeinek teljesítése érdekében. Az évek és kezelések szignifikanciáját a II. típusú Wald khi-négyzet teszttel határoztuk meg.

Végül, szignifikáns interakció esetén, a kezelések közötti szignifikáns különbségek kimutatására a Wald-tesztet alkalmaztuk post-hoc páros tesztként a 
„contrast” csomag használatával (Kuhn et al. 2016). Amennyiben nem volt interakció, a kezeléseket és éveket külön-külön vizsgáltuk a Tukey HSD teszt alapján a “multcomp" csomag segítségével (Hothorn et al. 2008). A statisztikai elemzéseket az R v. 3.5.1 (R Core Team 2018) alkalmazásával végeztük.

\section{Eredmények}

Az akác tömegességének alakulása

A három terület közül Bugacon volt a legerőteljesebb az akác újrasarjadása, ahol 1998-tól kezdődően szignifikáns különbség alakult ki a kontroll és kaszált parcellák között (2.a ábra). A kontroll parcellákban 2019-re az akác borítása átlagosan $30 \%$ körüli volt, a kaszált parcellákban 15\%. Fülöpházán és Izsákon mind a kontroll, mind a kezelt parcellákon visszaszorult az akác. Fülöpházán csak 1997-ben volt szignifikáns különbség a kaszált és kontroll parcellák között (2.b ábra). Izsákon a kezelések között nem volt szignifikáns különbség (2.c ábra), az akác borítása a letermelést követően csökkenő tendenciát mutatott. 2017-ben már egyáltalán nem találtunk sarjakat.

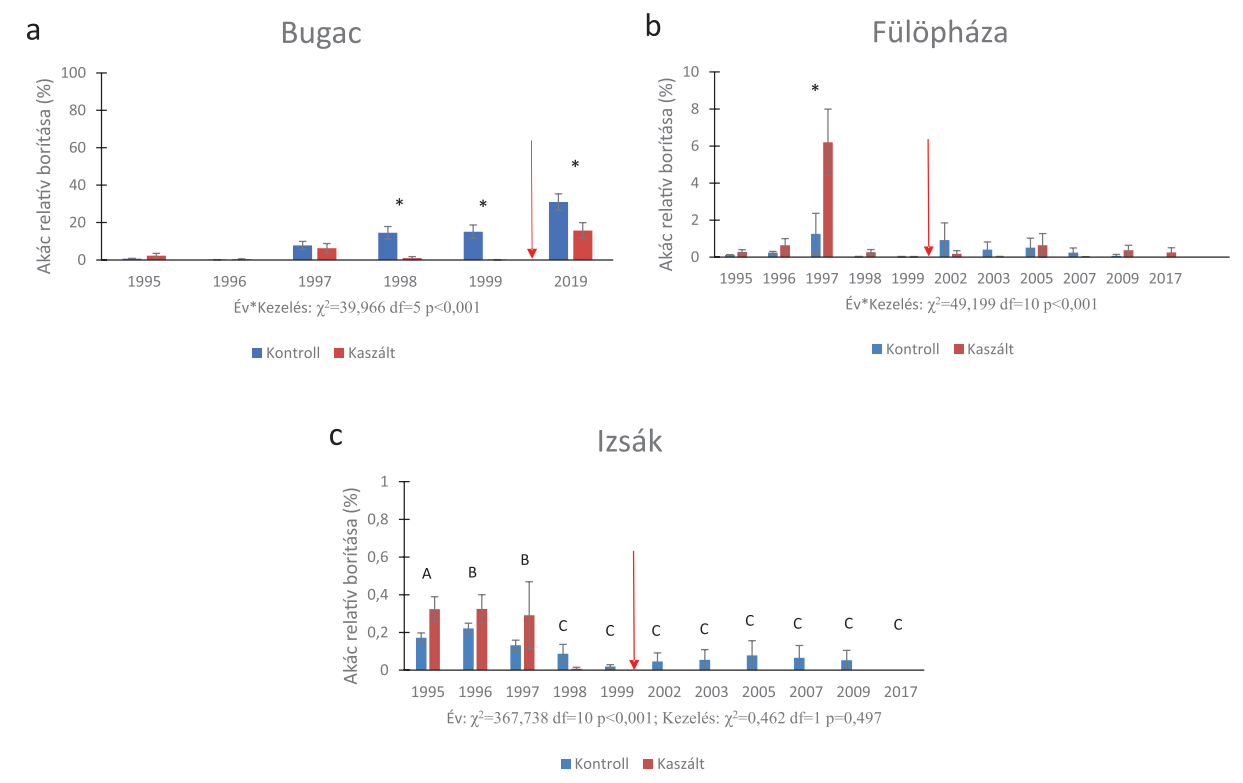

2. ábra: Az akác relatív borításának alakulása. Szignifikáns év-kezelés interakció esetén az azonos éven belül a kezelések közötti szignifikáns $(\mathrm{p}<0,05)$ különbségeket csillaggal jelöltük. Izsák esetén nem volt interakció, itt az évek közötti szignifikáns ( $\mathrm{p}<0,05)$ eltéréseket az oszlopok felett jelöltük nagybetűkkel. A piros nyíl a kaszálás végét jelzi. 


\section{A célfajok tömegességének alakulása}

Bugacon az akác kivágását követően mindössze $2 \%$ körülire nőtt a célfajok borítása, és a kaszált - kontroll parcellák nem különböztek egymástól (3.a ábra). A másik két területen a kaszált parcellákon a kontroll területekénél magasabb borítást értek el a célfajok az évek előrehaladtával (3.b és 3.c ábra). Mindkét területen csak a kaszálás megszüntetése után, Fülöpházán 2002-től, Izsákon 2003-tól volt szignifikáns az eltérés. Bár a kaszált területeken a célfajok borítása a 70-80\% százalékot is elérte egyes években, 22 évvel a beavatkozások megkezdése után is szignifikánsan eltértek a referencia gyepektől (kb. 100\%).

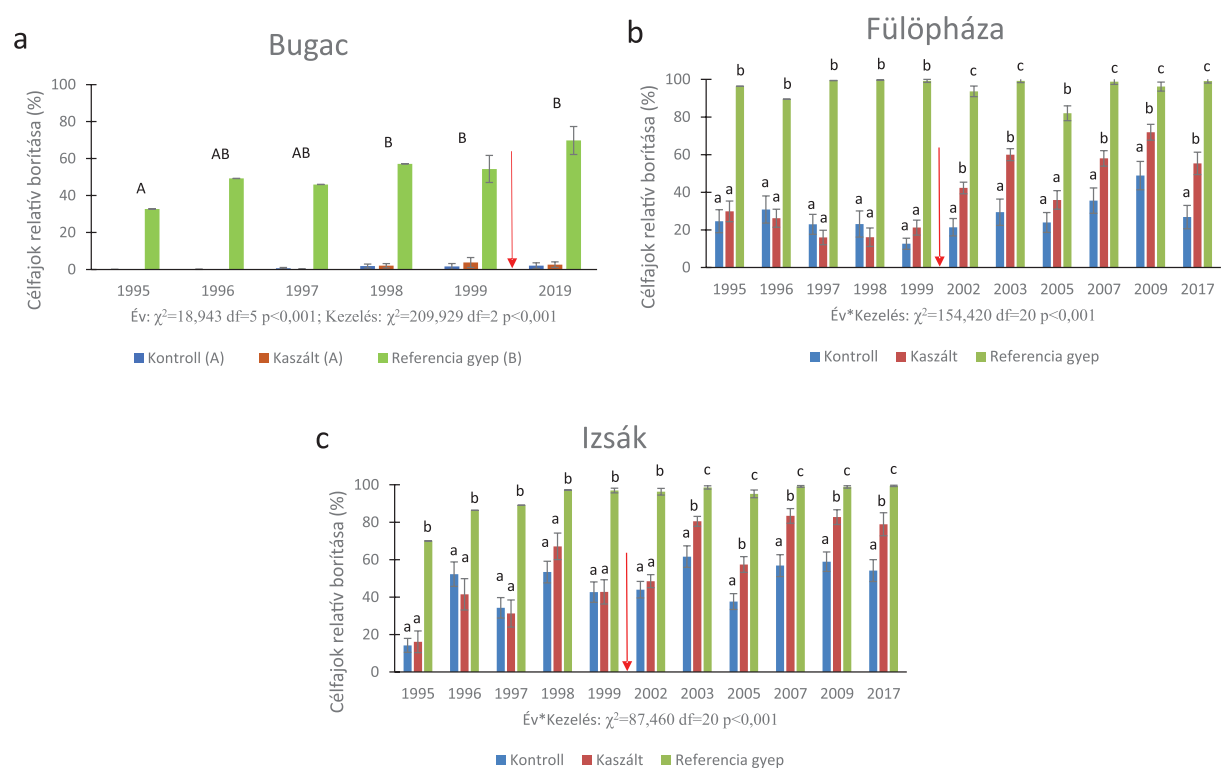

3. ábra: A nyílt homokpusztagyepi célfajok relatív borításának alakulása. Szignifikáns év-kezelés interakció esetén az azonos éven belül a kezelések közötti szignifikáns $(\mathrm{p}<0,05)$ különbségeket eltérő kisbetűkkel jelöltük. Bugac esetén nem volt interakció, itt az évek közötti szignifikáns $(p<0,05)$ eltéréseket az oszlopok felett, a kezelések közötti eltérést a jelmagyarázat mellett jelöltük nagybetűkkel. A piros nyíl a kaszálás végét jelzi.

Az idegenhonos fajok tömegességének alakulása

A nem-akác idegenhonos fajok a kaszált területeken idővel magasabb borítást értek el, mint a nem kaszált területeken (4. ábra). Ez alól Izsák a kivétel, ahol az idegenhonos fajok borítása (elsősorban betyárkóró - Conyza canadensis (L.) Cronquist) mind a kaszált, mind a kontroll parcellákban 3\% alá csökkent (4.c ábra). Bugacon 2019-ben a kaszált és a kontroll parcellákon rendre 27\% és $18 \%$ volt az idegenhonos fajok borítása (4.a ábra). Domináns faj a mirigyes bálványfa 
(Ailanthus altissima [Mill.] Swingle) volt, mellette megjelent a nyugati ostorfa (Celtis occidentalis L.). Fülöpházán az idegenhonos fajok borítása a kaszált parcellákon 30\% volt, míg a kontrollokban 3\% (4.b ábra). Mind a kaszált, mind a nem kaszált területeken meghatározó volt a betyárkóró, emellett a kaszált területeken tömeges volt a selyemkóró (Asclepias syriaca L.).

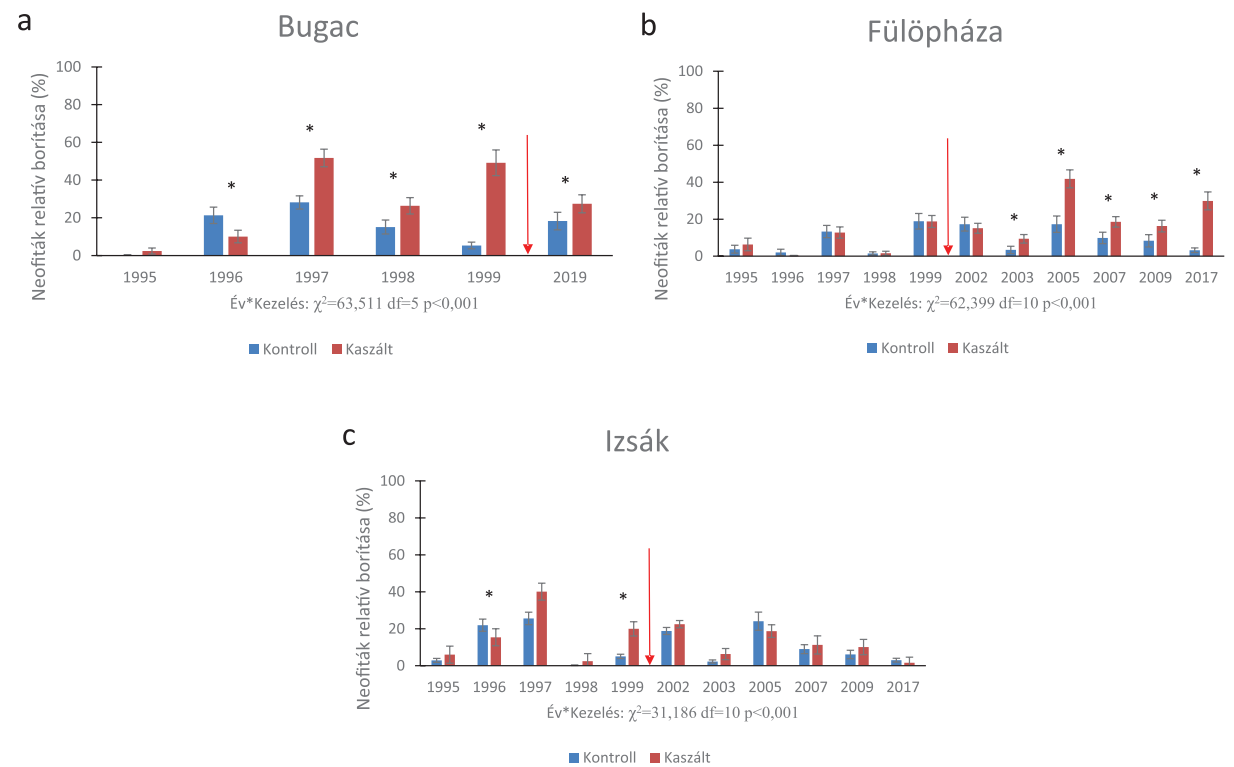

4. ábra: Az idegenhonos fajok relatív borításának alakulása. Szignifikáns év-kezelés interakció esetén az azonos éven belül a kezelések közötti szignifikáns $(\mathrm{p}<0,05)$ különbségeket csillaggal jelöltük. A piros nyíl a kaszálás végét jelzi.

\section{Diszkisszió}

A fehér akác felszámolása és az őshonos növényzet helyreállítása általában drága, és kockázatosnak tekinthető az akác nagymértékü sarjadása miatt (Sádlo et al. 2017; Vítková et al. 2017). Esetünkben a kivágás és a vegyszer tönkön történő alkalmazása sikeresnek bizonyult a nyílt táji környezetben, buckatetői helyzetben (feltehetően korábbi gyepi élőhelyeken) fekvő vágásérett állományok elleni küzdelemben. Az ilyen jellegü területeken az akác mind a kaszált, mind a kontroll területekről visszaszorult. Az újrasarjadás a bugaci, akácos és nyaras ültetvények közé ékelt állomány esetén volt a legerőteljesebb: míg a kontroll területeken 24 év alatt gyakorlatilag újranőtt az akácos, addig a kaszált területeken az akác alacsony borítással volt jelen, inkább csak a parcellák fölé benyúló lombkoronaszintben. 
Vagyis akácost is tartalmazó, erdős táji környezetben a vegyszeres kezelést követő rendszeres kezdeti kaszálás ajánlott az akác visszaszorítására.

A kezdeti kaszálás felgyorsította a nyílt homokpusztagyepi fajok betelepedését a fülöpházi és izsáki területeken a kontroll területekhez képest, de Bugacon nem. Ez feltehetően nem a talaj nitrogéntartalmától függött, mivel a letermelést követően a talaj nitrogéntartalma mindhárom területen lecsökkent mind a kontroll, mind a kezelt parcellákon, és 1999-ig nem különbözött szignifikánsan egymástól (Halassy 2004). A különbségek magyarázatát a táji környezet adja. Ahol a célfajok még mindig jelen vannak a tájban, ott a természetes regenerációs folyamatokra lehet támaszkodni a gyepterületek helyreállításakor (Csecserits et al. 2011). Ez igaz a fülöpházi és izsáki állományra, míg a bugaci állomány zárt nyaras-akácos ültetvényben, mint egy zárvány helyezkedett el, emiatt a homoki fajok propagulumai nem juthattak be a területre (Reis et al. early view). Ugyanakkor a kezdeti kaszálás kedvezett az egyéb idegenhonos fajok térnyerésének. A restaurációs célú kezelés, pl. a kaszálás többnyire zavarást okoz, amely betelepedésre alkalmas helyeket, ún. kolonizációs ablakokat hoz létre (Bartha et al. 2003). Amennyiben jelen vannak a tájban, jó terjedési képességeik miatt az inváziós fajok lehetnek az első betelepülök (Csecserits et al. 2016). A kontroll területeken a felnövő cserjés (Reis et al. early view) megakadályozta mind a lágyszárú homoki fajok, mind az idegenhonos fajok térnyerését.

Megállapítottuk, hogy nyílt táji környezetben az akácos letermelését követő vegyszeres kezelés, míg ültetvények közé zárt állomány esetén a vegyszeres kezelés kiegészítve hét évi kaszálással alkalmas volt az akác hosszú távú viszszaszorítására. Továbbá a kaszálás felgyorsította a nyílt homokpusztagyepi fajok betelepedését, amennyiben az állományt körülvevő tájban jelen voltak a homoki fajok propagulumai. Teljes helyreállításhoz a kaszálást kiegészítő többféle kezelés együttes alkalmazása, elsősorban magvetés, másodsorban az inváziós fajok célzott visszaszorítása javasolt. A beavatkozások kiválasztásakor figyelembe kell venni a táj konfigurációját és az ebből következő táji korlátokat. Végezetül a hoszszú távú monitorozás elengedhetetlen a vegetációs folyamatok megértéséhez és a beavatkozások értékeléséhez.

Köszönetnyilvánítás - A kutatást a Nemzeti Kutatási, Fejlesztési és Innovációs Hivatal támogatta (NKFIH FK127996). 


\section{Irodalomjegyzék}

Balogh, L., Dancza, I. \& Király, G. (2004): A magyarországi neofitonok időszerü jegyzéke és besorolásuk inváziós szempontból. - In: Mihály, B. \& Botta-Dukát, Z. (szerk.): Özönnövények. Természetbúvár Alapítvány Kiadó, Budapest, pp. 61-92.

Bartha, D., Csiszár, Á., Zagyvai, G. \& Zsigmond, V. (2012): Fehér akác (Robinia pseudoacacia L.). - In: Csiszár, Á. (szerk.): Inváziós növényfajok Magyarországon. Nyugat-magyarországi Egyetem, Sopron, pp. 127-131.

Bartha, S., Meiners, S. J., Pickett, S. T. \& Cadenasso, M. L. (2003). Plant colonization windows in a mesic old field succession. - Appl. Veg. Sci. 6: 205-212. https://doi.org/10.1111/j.1654109X.2003.tb00581.X

Bolla, B. (2012): Inváziós növények irtása a Csengődi-síkon. - Termvéd Közlem. 18: 77-81.

Botta-Dukát, Z. (2008): Invasion of alien species to Hungarian (semi-) natural habitats. - Acta Bot. Hung. 50: 219-227.

Braun-Blanquet, J. (1965): Plant-Sociology: The Study of Plant Communities. - Hafner, London.

Corbin, J. D. \& D'Antonio, C. M. (2012): Gone but not forgotten? Invasive plants' legacies on community and ecosystem properties. - Invas. Plant Sci. Mana. 5: 117-124. https://doi.org/10.1614/ IPSM-D-11-00005.1

Csecserits, A., Czúcz, B., Halassy, M., Kröel-Dulay, Gy., Rédei, T., Szabó, R., Szitar, K. \& Török, K. (2011): Regeneration of sandy old-fields in the forest steppe region of Hungary. - Plant Biosyst. 145: 715-729. https:// doi.org/10.1080/11263504.2011.601340

Csecserits, A., Botta-Dukát, Z., Kröel-Dulay, Gy., Lhotsky, B., Ónodi, G., Rédei, T., Szitár, K. \& Halassy, M. (2016): Tree plantations are hot-spots of plant invasion in a landscape with heterogeneous land-use. - Agric. Ecosyst. Environ. 226: 88-98. https://doi.org/10.1016/j.agee.2016.03.024

Csiszár, Á. \& Korda, M. (szerk.) (2015): Özönnövények visszaszoritásának gyakorlati tapasztalatai. Rosalia kézikönyvek 3. - Duna-Ipoly Nemzeti Park Igazgatóság, Budapest, 239 p.

Demeter, A., Sarlós, D., Skutai, J., Tirczka, I., Ónodi, G. \& Czóbel, Sz. (2015): Kiválasztott özönfajok gazdasági szempontú értékelése - a fehér akác és a mirigyes bálványfa. - Tájökológiai Lapok 13: 193-201.

Halassy, M. (2004): A nyilt homokpusztagyep regenerációjának és restaurációjának lehetöségei degradált területeken. - PhD értekezés. ELTE, Budapest, $151 \mathrm{p}$.

Hothorn, T., Bretz, F. \& Westfall, P. (2008): Simultaneous inference in general parametric models. - Biometrical J. 50: 346-363. https://doi.org/10.1002/bimj.200810425

Kuhn, M., Weston, S., Wing, J. \& Forester, J. (2016): The Contrast Package. - $\underline{\text { http://cran.ma.ic. }}$ ac.uk/web/packages/contrast/vignettes/contrast.pdf

Ónodi, G., Altbäcker, V., Aszalós, R., Botta-Dukát, Z., Hahn, I. \& Kertész, M. (2014): Long-term weather sensitivity of open sand grasslands of the Kiskunság Sand Ridge forest-steppe mosaic after wildfires. - Community. Ecol. 15: 121-129.

Ónodi, G. (2016): Az idegenhonos, illetve inváziós fafajok élőhelyformáló hatásai. - Erdészettudományi Közlem. 6: 101-113.

Pinheiro, J., Bates, D., DebRoy, S., Sarkar, D., Heisterkamp, S., Van Willigen, B. \& Maintainer, R. (2017): Package 'nlme'. Linear and nonlinear mixed effects models, 3-1. - R package version 3.1-128. https://cran.r-project.org/web/packages/nlme/index.html

$\mathrm{R}$ Core Team (2018): $R$ : A language and environment for statistical computing. - $\mathrm{R}$ Foundation for Statistical Computing, Vienna. http://www.R-project.org/

Reis, B. P., Kövendi-Jakó, A., Szitár, K., Török, K. \& Halassy, M. (early view): Long-term effect of mowing on the restoration of Pannonian sand grassland to replace invasive black locust plantation. - Restor. Ecol. https://doi.org/10.1111/rec.13152 
Sala, O. E., Chapin, F. S., Armesto, J. J., Berlow, E., Bloomfield, J., Dirzo, E., Huber-Sanwald, E., Huenneke, L. F., Jackson, R. B., Kizing, A., Leemans, R., Lodge, D. M., Mooney, H. A., Oesterheld, M., Poff, N. L., Sykes, M. T., Walker, B. H., Walker, M. \& Wall, D. H. (2000): Global biodiversity scenarios for the year 2100. - Science 287: 1770-1774. https://doi.org/10.1126/science.287.5459.1770

Sádlo, J., Vítková, M., Pergl, J. \& Pyšek, P. (2017): Towards site-specific management of invasive alien trees based on the assessment of their impacts: the case of Robinia pseudoacacia. - NeoBiota 35: 1-34. https://doi.org/10.3897/neobiota.35.11909

Tilman, D. \& Isbell, F. (2015): Biodiversity: recovery as nitrogen declines. - Nature 528: 336. https://doi.org/10.1038/nature16320

Tölgyesi, Cs., Török, P., Hábenczyus, A. A., Bátori, Z., Valkó, O., Deák, B., Tóthmérész, B., Erdős, L. \& Kelemen, A. (2020): Underground deserts below fertility islands? Woody species desiccate lower soil layers in sandy drylands. - Ecography 43: 848-859. https://oi.org/10.1111/ ecog.04906

Török, K., Botta-Dukát, Z., Dancza, I., Németh, I., Kiss, J., Mihály, B. \& Magyar, D. (2003): Invasion gateways and corridors in the Carpathian Basin: biological invasions in Hungary. - Biol. Invasions 5: 349-356. https://doi.org/10.1023/B:BINV.0000005570.19429.73

Török, K., Szitár, K., Halassy, M., Szabó, R., Szili-Kovács, T., Baráth, N. \& Paschke, M. W. (2014): Long-term outcome of nitrogen immobilization to restore endemic sand grassland in Hungary. J. Appl. Ecol. 51: 756-765. https://doi.org/10.1111/1365-2664.12220

Vítková, M., Müllerová, J., Sádlo, J., Pergl, J. \& Pyšek, P. (2017): Black locust (Robinia pseudoacacia) beloved and despised: A story of an invasive tree in Central Europe. - Forest Ecol. Manag. 384: 287-302. https://doi.org/10.1016/j.foreco.2016.10.057

Zólyomi, B. (1951): Növényszociológiai alapfogalmak és felvételezési módszerek. - In: Soó, R. \& Zólyomi, B. (szerk.) Növényföldrajzi-térképezési tanfolyam jegyzete. Vácrátót, pp. 103-107. 


\title{
Possibilities to restore open sand grassland at clear-cut black locust stands: long-term effect of mowing
}

\author{
Melinda Halassy ${ }^{1}$, Anna Kövendi-Jakó ${ }^{1}$, Bruna Paolinelli Reis ${ }^{2}$, \\ Nóra Sáradi ${ }^{3}$, Katalin Szitár ${ }^{1} \&$ Katalin Török ${ }^{1}$ \\ ${ }^{1}$ Centre for Ecological Research, Institute of Ecology and Botany, \\ H-2163 Vácrátót, Alkotmány u. 2-4., Hungary \\ ${ }^{2}$ Eötvös Loránd University, Department of Plant Taxonomy, Ecology and Theoretical \\ Biology, H-1117, Budapest, Pázmány P. stny. 1/C, Hungary \\ ${ }^{3}$ Szent István University, Environmental Sciences PhD School, \\ H-2100 Gödöllö, Páter Károly u. 1., Hungary \\ E-mail:halassy.melinda@ecolres.hu
}

Invasive species are among the main threats to grassland biodiversity, and nature conservation management is constantly looking for effective ways to eliminate them, and so to restore natural habitats. We studied the long-term effects of mowing on the recovery of Pannonian sand grasslands after the elimination of invasive black locust (Robinia pseudoacacia) plantations in Hungary, Europe. Stands of $R$. pseudoacacia had been felled and their stumps treated with herbicides at three sites in the winter of 1994/1995. Between 1995 and 2001, the sites were mowed and the hay removed twice a year, to assist grassland recovery. A block of twelve adjacent plots of $10 \mathrm{~m}$ by $10 \mathrm{~m}$ was assigned for the experiment at each site with six control (unmowed) and six treatment (mowed) plots, randomly distributed. The vegetation was sampled in June and August, between 1995 and 1999 yearly at every site, complemented by samplings in semi-natural reference grasslands, then re-sampled six times until 2017 in Izsák and Fülöpháza, plus once (2019) in Bugac. Chemical treatment successfully repressed $R$. pseudoacacia in stands surrounded by mostly open landscapes. However, in the lack of regular mowing, $R$. pseudoacacia could re-establish at the Bugac site, which was surrounded by forest plantation. A higher cover of target species could be found in mowed compared to unmowed plots at sites mostly surrounded by grasslands, though their cover was still significantly lower than at reference sites, as mowing facilitated the spread of neophyte species as well. Long-term monitoring revealed that initial mowing facilitated the recovery of the Pannonian sand grassland, but further management is needed to control secondary invasion and to increase target species cover.

Keywords: black locust, grassland restoration, long-term monitoring, invasion, mowing, open sand grassland 